\title{
Beyond the circulating renin-angiotensin aldosterone system
}

\section{Walmor C. De Mello*}

School of Medicine, Medical Sciences Campus, University of Puerto Rico, San Juan, PR, USA

*Correspondence: walmor.de-mello@upr.edu

\section{Edited by:}

Kevin D. G. Pfleger, Harry Perkins Institute of Medical Research, Australia

Reviewed by:

Nicola J. Smith, Victor Chang Cardiac Research Institute, Australia

Keywords: renin-angiotensin systems, editorial, RAAS, pathophysiology, oxidative stress

The activation of the classical renin-angiotensin aldosterone system (RAAS) is known to be involved in the regulation of blood volume and blood pressure and plays an important role in cardiovascular pathology including hypertension and heart failure. Evidence is now available that independently of the classical RAAS, several RAAS components are expressed in cells from different organs including the heart and kidney and are able to change important physiological properties like cell communication, heart excitability, and activation of ionic channels and cell volume when applied locally to the cells (1) or systemically, independently of blood pressure. In cardiac cells, swelling induced by angiotensin II (Ang II), is counteracted by angiotensin (1-7) [Ang (1-7)] with consequent decrease of swelling-dependent chloride current helping the re-establishment of cell volume (2). Recently, it was found that Ang (1-7) re-establishes cell communication impaired by cell swelling in cardiac muscle raising the possibility of a beneficial effect of the hexapeptide during myocardial ischemia (3). These findings have important clinical implications $(1,4)$ and represent a novel and fruitful pathway to be followed to better understand the role of the RAAS in different pathological conditions. Furthermore, they offer the opportunity for the development of new therapeutic agents.

Although studies performed on transgenic animals generated controversial results, evidence is available that the overexpression of some components of RAAS like Ang II on cardiac muscle, elicit ventricular hypertrophy independently of changes in arterial blood pressure (5). Furthermore, the identification of some of the RAAS components inside the cell including the nucleus and mitochondria (6-8) and the results achieved dialyzing Ang II or renin intracellularly $(1,7)$, supports the notion that there is an intracellular component with functional properties (the intracrine effect) $(1,7)$. In arterial myocytes from vascular resistance vessels, for instance, intracellular Ang II has an effect opposite to that of extracellular Ang II on vascular tone (9) suggesting an important intracrine effect of the peptide on peripheral resistance. Furthermore, the (pro) renin receptor (PRR), mainly located intracellularly $(10,11)$, is a new member of the RAS, originally considered to be involved in the regulation of blood pressure. Recent observations using transgenic animals over-expressing PRR demonstrated that PRR is an accessory protein of V-ATPase that plays an important role in the regulation of several cellular homeostatic processes including autophagy (11).
The harmful effects of Ang II on cardiovascular and renal systems inducing remodeling, seems, in part, related to increase in oxidative stress. The discovery of angiotensin converting enzyme 2 (ACE2) (12) and the evidence that it promotes the formation of Ang (1-7) from Ang II in animal models, represented an important chapter in the studies of RAAS because Ang (1-7) counteracts many effects of Ang II (13) including the enhancement of oxidative stress induced by Ang II. Further studies are, however, necessary to confirm if these beneficial effects of Ang (1-7) are present in humans.

In this Research Topic, the pathophysiological role of local RAAS in different tissues and organs are reviewed by different authors, each one expert in their respective fields (14-18). We hope these articles will help the development of future investigation of this important topic.

\section{REFERENCES}

1. De Mello WC, Frohlich ED. Clinical perspectives and fundamental aspects of local cardiovascular and renal renin-angiotensin systems. Front Endocrinol (Lausanne) (2014) 5:16. doi:10.3389/fendo.2014.00016

2. De Mello WC. Cell swelling, impulse conduction, and cardiac arrhythmias in the failing heart. Opposite effects of angiotensin II and angiotensin (1-7) on cell volume regulation. Mol Cell Biochem (2009) 330(1-2):211-7. doi:10.1007/ s11010-009-0135-0

3. De Mello WC. Angiotensin (1-7) re-establishes heart cell communication previously impaired by cell swelling: implications for myocardial ischemia. Exp Cell Res (2014) 323(2):359-65. doi:10.1016/j.yexcr.2014.03.006

4. Frohlich ED. Hypertensive heart diseases: time for new paradigms. In: Frohlich ED, Re RN, editors. The Local Cardiac Renin Angiotensin System. New York, NY: Springer (2006). p. 1-5.

5. Mazzolai L, Nussberger J, Aubert JF, Brunner DB, Gabbiani G, Brunner HR, et al. Blood pressure-independent cardiac hypertrophy induced by locally activated renin-angiotensin system. Hypertension (1998) 31(6):1324-30. doi:10.1161/01. HYP.31.6.1324

6. Abadir PM, Walston JD, Carey RM. Subcellular characteristics of functional intracellular renin-angiotensin systems. Peptides (2012) 38(2):437-45. doi:10. 1016/j.peptides.2012.09.016

7. De Mello WC. Is an intracellular renin-angiotensin system involved in control of cell communication in heart? J Cardiovasc Pharmacol (1994) 23(4):640-6. doi:10.1097/00005344-199404000-00018

8. Chappell MC, Marshall AC, Alzayadneh EM, Shaltout HA, Diz DI. Update on the angiotensin converting enzyme 2-angiotensin (1-7)-Mas receptor axis: fetal programing, sex differences, and intracellular pathways. Front Endocrinol (Lausanne) (2014) 4:201. doi:10.3389/fendo.2013.00201

9. De Mello WC. Intracellular angiotensin II increases the total potassium current and the resting potential of arterial myocytes from vascular resistance vessels of the rat. J Am Soc Hypertens (2013) 7(3):192-7. doi:10.1016/j.jash.2013.02.003 
10. Schefe JH, Menk M, Reinemund J, Effertz K, Hobbs RM, Pandolfi PP, et al. A novel signal transduction cascade involving direct physical interaction of the renin/prorenin receptor with the transcription factor promyelocytic zinc finger protein. Circ Res (2006) 99:1355-66. doi:10.1161/01.RES.0000251700.00994.0d

11. Binger KJ, Muller DN. Autophagy and the (pro)renin receptor. Front Endocrinol (Lausanne) (2013) 4:155. doi:10.3389/fendo.2013.00155

12. Donoghue M, Hsieh F, Baronas E, Godbout K, Gosselin M, Stagliano N, et al. A novel angiotensin-converting enzyme-related carboxypeptidase (ACE2) converts angiotensin I to angiotensin 1-9. Circ Res (2000) 87(5):E1-9. doi:10.1161/ 01.RES.87.5.e1

13. Ferrario CM, Ahmad S, Nagata S, Simington SW, Varagic J, Kon N. Dell'italia LJ. An evolving story of angiotensin-II-forming pathways in rodents and humans. Clin Sci (Lond) (2014) 126(7):461-9. doi:10.1042/CS20130400

14. Zhuo JL, Ferrao FM, Zheng Y, Li XC. New frontiers in the intrarenal reninangiotensin system: a critical review of classical and new paradigms. Front Endocrinol (Lausanne) (2013) 4:166. doi:10.3389/fendo.2013.00166

15. Wright JW, Kawas LH, Harding JW. A role for the brain RAS in Alzheimer's and Parkinson's diseases. Front Endocrinol (Lausanne) (2013) 4:158. doi:10.3389/ fendo.2013.00158

16. Aroor AR, Demarco VG, Jia G, Sun Z, Nistala R, Meininger GA, et al. The role of tissue renin-angiotensin-aldosterone system in the development of endothelial dysfunction and arterial stiffness. Front Endocrinol (Lausanne) (2013) 4:161. doi:10.3389/fendo.2013.00161
17. Rodgers KE, Dizerega GS. Contribution of the local RAS to hematopoietic function: a novel therapeutic target. Front Endocrinol (Lausanne) (2013) 4:157. doi:10.3389/fendo.2013.00157

18. Herr D, Bekes I, Wulff C. Local renin-angiotensin system in the reproductive system. Front Endocrinol (Lausanne) (2013) 4:150. doi:10.3389/fendo.2013. 00150

Conflict of Interest Statement: The author declares that the research was conducted in the absence of any commercial or financial relationships that could be construed as a potential conflict of interest.

Received: 02 May 2014; accepted: 18 June 2014; published online: 02 July 2014.

Citation: De Mello WC (2014) Beyond the circulating renin-angiotensin aldosterone system. Front. Endocrinol. 5:104. doi: 10.3389/fendo.2014.00104

This article was submitted to Cellular Endocrinology, a section of the journal Frontiers in Endocrinology.

Copyright (c) 2014 De Mello. This is an open-access article distributed under the terms of the Creative Commons Attribution License (CC BY). The use, distribution or reproduction in other forums is permitted, provided the original author(s) or licensor are credited and that the original publication in this journal is cited, in accordance with accepted academic practice. No use, distribution or reproduction is permitted which does not comply with these terms. 